\begin{tabular}{lr}
\hline Jurnal Abdimas llmiah & JURNAL ABDIMAS ILMIAH CITRA BAKTI \\
Citra Bakti & Volume 2, Nomor 2, November 2021 \\
$(\mathrm{JAICB})$ & ISSN 2721-9178 \\
\hline
\end{tabular}

\title{
PELATIHAN E-LEARNING DASAR BAGI GURU-GURU BIDANG STUDI IPS SE KOTA KEFAMENANU
}

\author{
Darsono Nababan"1), Krisantus J Tey Seran²), Yasinta O L Rema ${ }^{3)}$, Yosep P K Kelen ${ }^{4)}$ \\ 1,2,3,4)Program Studi Teknologi Informasi, Universitas Timor \\ 1) darsono.nababan@unimor.ac.id, 2) iva.rema@gmail.com
}

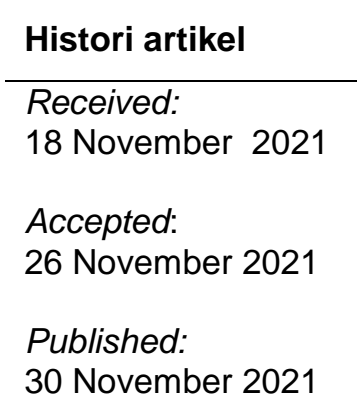

\begin{abstract}
Abstrak
Masa darurat COVID-19 mengubah sistem pendidikan di Indonesia dalam waktu yang sangat singkat yang mengharuskan setiap siswa melakukan pembelajaran dengan jarak jauh. Tentu hal ini mendorong para guru berinovasi serta pengambil kebijakan dalam hal ini adalah Kementerian Pendidikan dan Kebudayaan Republik Indonesia melakukan upaya penyesuaian selama pandemi COVID-19 dengan merubah beberapa aturan melalui denga mengelurkan surat edaran nomor 2 tahun 2020 tentang pencegahan dan penanganan COVID-19 di lingkungan Kemendikbud, serta surat edaran nomor 3 tahun 2020 tentang pencegahan COVID-19 pada satuan pendidikan. Kesiapan sekolah-sekolah dalam pelaksanaan pembelajaran jarak jauh mendapat berbagai tanggapan positif dan negatif dari berbagai elemen masyarakat. Kesiapan guru dalam pelaksanaan Pendidikan secara daring belum maksimal hal ini disebabkan oleh minimnya pengetahuan dalam bidang Teknologi Informasi. Oleh karena itu untuk mendukung kebijakan pemerintah dalam penerapan pembelajaran jarak jauh dan meminimalisir penyebaran virus COVID-19 guru-guru perlu dibekali tentang implementasi elearning. Para guru-guru diharapkan mampu menyusun materi pembelajaran secara e-learning online dengan menggunakan platform Edmodo sehingga para guru tidak hanya terpaku pada satu model pembelajaran dengan menggunakan model konvensional saja.
\end{abstract}

Kata-kata Kunci: Covid-19, E-Learning, Edomodo 
Abstract. The COVID-19 emergency period changed the education system in Indonesia in a very short time, requiring every student to study remotely. Of course this encourages teachers to innovate and policy makers in this case the Ministry of Education and Culture of the Republic of Indonesia to make adjustments during the COVID-19 pandemic by changing some rules by issuing circular letter number 2 of 2020 regarding the prevention and handling of COVID-19 in the environment. Ministry of Education and Culture, as well as circular letter number 3 of 2020 regarding the prevention of COVID-19 in education units. The readiness of schools in implementing distance learning received various positive and negative responses from various elements of society. The readiness of teachers in the implementation of online education has not been maximized, this is due to the lack of knowledge in the field of Information Technology. Therefore, to support government policies in implementing distance learning and minimizing the spread of the COVID-19 virus, teachers need to be equipped with e-learning implementation. Teachers are expected to be able to compile learning materials using online e-learning using the Edmodo platform so that teachers are not only fixated on one learning model using conventional models.

Keywords: Covid-19, E-Learning, Edomodo

\section{PENDAHULUAN}

Masa darurat COVID-19 mengubah sistem pendidikan di Indonesia dalam waktu yang sangat singkat yang mengharuskan setiap siswa melakukan pembelajaran dengan jarak jauh. Tentu hal ini mendorong para guru berinovasi serta pengambil kebijakan dalam hal ini adalah Kementerian Pendidikan dan Kebudayaan Republik Indonesia melakukan upaya penyesuaian selama pandemi COVID-19 dengan merubah beberapa aturan melalui dengan mengelurkan surat edaran nomor 2 tahun 2020 tentang pencegahan dan penanganan COVID19 di lingkungan Kemendikbud, serta surat edaran nomor 3 tahun 2020 tentang pencegahan COVID-19 pada satuan pendidikan. Kesiapan sekolah-sekolah dalam pelaksanaan pembelajaran jarak jauh mendapat berbagai tanggapan positif dan negatif dari berbagai elemen masyarakat. Kesiapan guru dalam pelaksanaan Pendidikan secara daring belum maksimal hal ini disebabkan oleh minimnya pengetahuan dalam bidang Teknologi Informai.

Selain itu seiring perkembangan zaman proses kegiatan belajar mengajar di kelas kini sudah memiliki banyak tantangan dan tuntutan. Salah satunya adalah semakin banyaknya jalur informasi yang dapat diakses oleh siswa hingga terkadang tidak jarang guru tertinggal jauh dari update-nya informasi yang sudah diterima oleh siswa. Oleh karena itu guru pun seolah-olah dipaksa harus mengimbanginya denga mencari berbagai informasi tambahan menggunakan berbagai media seperti akses internet dan buku refrensi terbaru dan up to date.

Selain terkait dengan konten materi pembelajaran, saat ini juga telah muncul berbagai macam alternatif strategi belajar mengajar yang dapat diterapkan oleh guru, sehingga guru tidak hanya terpaku pada satu model pembelajaran saja. Mulai dari yang menggunakan metode konvensional hingga mengarah pada penggunaan media yang tergolong sangat maju. Salah satu strategi belajar yang belum banyak diterapkan saat ini adalah strategi belajar $E$ Learning. Salah satu definisi umum dari e-learning diberikan Gilbert \& Jones (2001), yaitu: pengiriman materi pembelajaran melalui suatu media elektronik seperti internet, 
intranet/extranet, satellite broadcast, audio/video tape, interactive TV, CD-ROM, dan computer-based training (CBT).

E-Learning belum banyak diterapkan oleh guru karena kebanyakan guru menganggap strategi ini membutuhkan sarana dan prasarana yang cukup mahal dan kebanyakan sekolah belum fasilitas yang dianggap mendukung. Padahal pada kenyataannya, e-learning tidak harus menggunakan fasilitas yang tergolong mahal dan harus memiliki website e-learning sendiri. Saat ini sudah banyak website e-learning yang bersifat free access dan tidak berjangka waktu. Masalah ini juga dipertegas oleh Heru Suhartanto (2010) yang merincikan tentang beberapa faktor yang mendukung e-learning sudah cukup layak untuk dipakai di sekolah Indonesia : 1) Siswa tingkat SMP dan SMA sudah sangat pandai memanfaatkan TIK dalam aktifitas sehari-hari. 2) Banyak sekolah telah memiliki perangkat komputer, namun hanya digunakan sebagai perangkat administrasi saja. 3) Telah tersedianya beberapa sistem pendukung elearning, bahkan sudah banyak yang tersedia dalam bentuk open source atau juga yang gratis seperti Moodle.

Terkait dengan beberapa faktor di atas, salah satu akses website e-learning yang dapat dimanfaatkan secara tidak berbayar adalah Edmodo. Edmodo adalah website e-learning tidak berbayar yang dapat dimanfaatkan oleh guru untuk menjadi salah satu media dalam menerapkan strategi belajar e-learning. Namun saat ini belum banyak guru-guru yang mengetahui akan adanya media ini dan ataupun memanfaatkannya secara maksimal dalam membantu proses belajar mengajar di kelas. Kelebihan dari media website ini adalah media ini tidak hanya dapat diakses melalui media laptop saja, namun Edmodo ini juga sudah tersedia dan bisa diakses dalam bentuk aplikasi android. Hal ini bisa mempermudah guru dalam memantau kinerja dan interaksi antara guru dan siswa melalui smartphone maupun gadget berbasis android lainnya. Penerapan strategi belajar e-learning ini juga dapat membantu guru untuk menggantikan proses belajar mengajar yang ada di kelas dan dibawa menjadi interaksi dalam dunia maya melalui website elearning Edmodo ini pada siswa. Sehingga tidak ada alasan lagi bagi siswa akan tidak memiliki aktifitas di kelas ketika guru memiliki kesibukan atau acara di luar kelas pada saat jam pelajaran.

Oleh karena itu untuk mendukung kebijakan pemerintah dalam penerapan pembelajaran jarak jauh dan meminimalisir penyebaran virus COVID-19 guru-guru perlu dibekali tentang implementasi e-learning. Para guru-guru diharapkan mampu menyusun materi pembelajaran secara e-learning online dengan menggunakan platform Edmodo sehingga para guru tidak hanya terpaku pada satu model pembelajaran dengan menggunakan model konvensional saja.

\section{METODE PELAKSANAAN}


Strategi belajar mengajar e-learning membutuhkan berbagai macam persiapan yang harus dipersiapkan oleh guru. Dalam pelatihan ini memiliki tujuan akhir memberikan keterampilan bagi guru-guru SMP bidang studi IPS dalam menyiapkan materi dan merancang proses pembelajaran menggunakan elearning berbasis online dengan menggunakan website Edmodo.

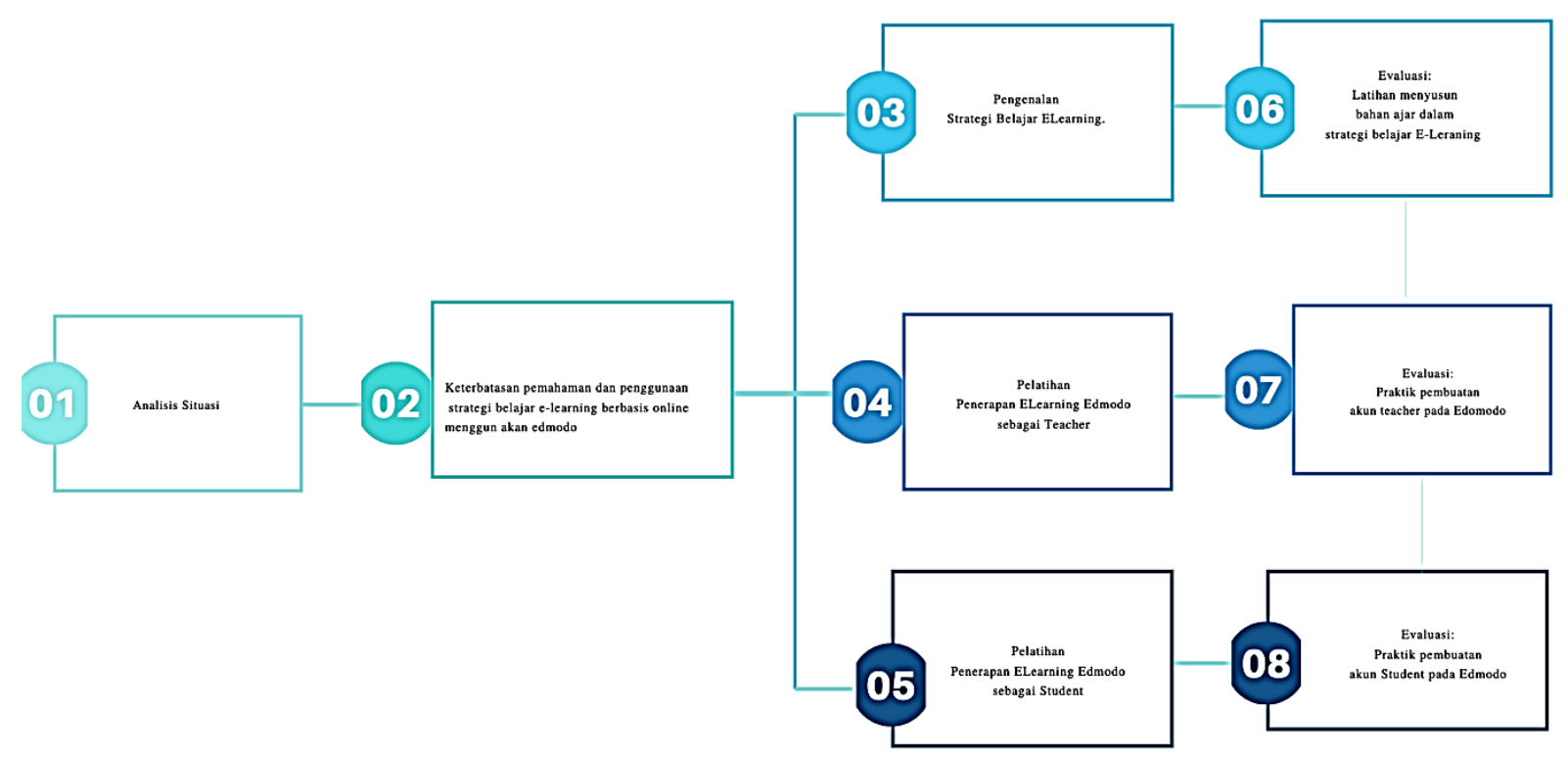

\section{Gambar 1. Kerangka Pemecahan Masalah}

1. Khalayak Sasaran

Khalayak sasaran pengabdian masyarakat ini adalah guru SMP bidang studi IPS

se-

Kota Kefamenanu dengan jumlah sekolah sebanyak 12 Sekolah yang ditunjukkan pada tabel berikut ini :

Tabel 1. Data guru Bidang Studi IPS SMP Se-Kota Kefamenanu

\begin{tabular}{llc}
\hline NO & \multicolumn{1}{c}{ Nama Sekolah } & $\begin{array}{c}\text { Jumlah Guru Bidang } \\
\text { Studi IPS }\end{array}$ \\
\hline 1 & SMP Negeri 1 Kefamenanu & 3 \\
2 & SMP Negeri 2 Kefamenanu & 2 \\
3 & SMP Negeri Fatumfaun & 1 \\
4 & SMP Negeri Neonbat & 1 \\
5 & SMP Satu Atap Negeri Maumolo & 1 \\
6 & SMPK Putri St.Xaverius Kefamenanu & 2 \\
7 & SMPK Putra St.XAverius Kefamenanu & 2 \\
8 & SMP Swasta Aurora Kefamenanu & 1 \\
9 & SMP Kristen Kefamenanu & 1 \\
10 & SMP St.Antonius Padua & 1 \\
11 & MTS Nuruf Falah Kefamenanu & 1 \\
12 & SMP Negeri Maubeli & 1
\end{tabular}

Sumber : Dinas Pendidikan Kepemudaan dan Olah Raga Kabupaten Timur Tengah

Utara 


\section{Metode Kegiatan}

Pelatihan diselenggarakan dengan ceramah, tanya jawab, dan praktik.

a. Ceramah dan Tanya Jawab

Analisis situasi saat ini adalah :

1. Keterbatasan pemahaman dan penggunaan teknologi informasi sebagai strategi belajar e-learning berbasis online menggunakan edmodo.

2. Penerapan e-learning Edmodo sebagai Teacher

3. Penerapan e-learning Edmodo sebagai Student

Evaluasi terhadap analisi situasi diatas adalah : Latihan menyusun bahan ajar dalam strategi belajar E-Learning Evaluasi: Praktik pembuatan akun teacher pada edmodo. Praktik pembuatan akun Student pada edmodo. Metode ini bertujuan untuk menyampaikan rangkaian materi tentang Strategi Belajar Mengajar e-learning dan tahapan serta proses pembelajaran menggunakan Edmodo secara online.

b. Praktik

Pada sesi ini, peserta pelatihan akan dibimbing dalam menyiapkan dan menyusun proses strategi belajar mengajar e-learning berbasis online menggunakan Edmodo.

\section{Rancangan Evaluasi}

Target kegiatan ini pengabdian masyarakat ini adalah untuk meningkat pengetahuan dan keterampilan guru IPS dalam memanfaatkan dan mengembangkan strategi belajar elearning berbasis website online menggunakan Edmodo pada SMP bidang studi IPS se-Kota Kefamenanu. Paradigma evaluasi ketercapaian target kegiatan adalah sebagai berikut:

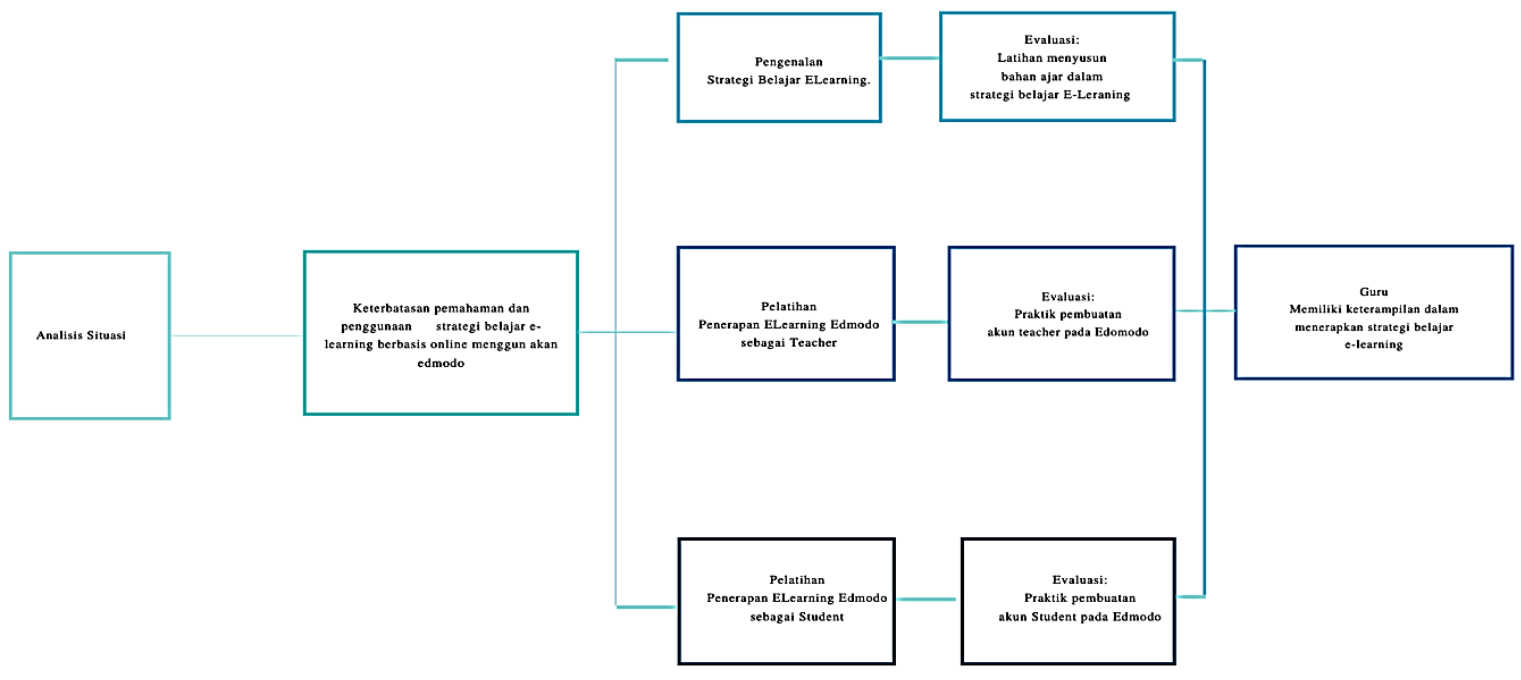

Gambar 2. Rancangan Evaluasi Ketercapaian Target Kegiatan 


\section{HASIL DAN PEMBAHASAN}

Hasil

Pengabdian pada masyarakat bagi guru Bidang Studi IPS Se Kota Kefamenanu dilaksanakan pada hari/tanggal Kamis - Jumat, 29-30 Juli 2021, pukul 09.00 - 16.00 WIB. Pengabdian pada masyarakat dilaksanakan di Laboratorium SMP Negeri 1 Kefamenanu.

Hasil yang diperoleh dari pengabdian ini adalah sebagai berikut :

a. Materi Strategi Belajar Megajar dan Pengenalan E-Learning diantaranya E-learning sebagai Student, Penerapan E-learning sebagai Teacher adalah materi yang diberikan pada dalam pengabdian ini.Sebelum melaksanakan kegiatan pelatihan terlebih dahulu menjelaskan sejarah edmodo dan fitu-fitur yang yang terdapat di Edmodo.

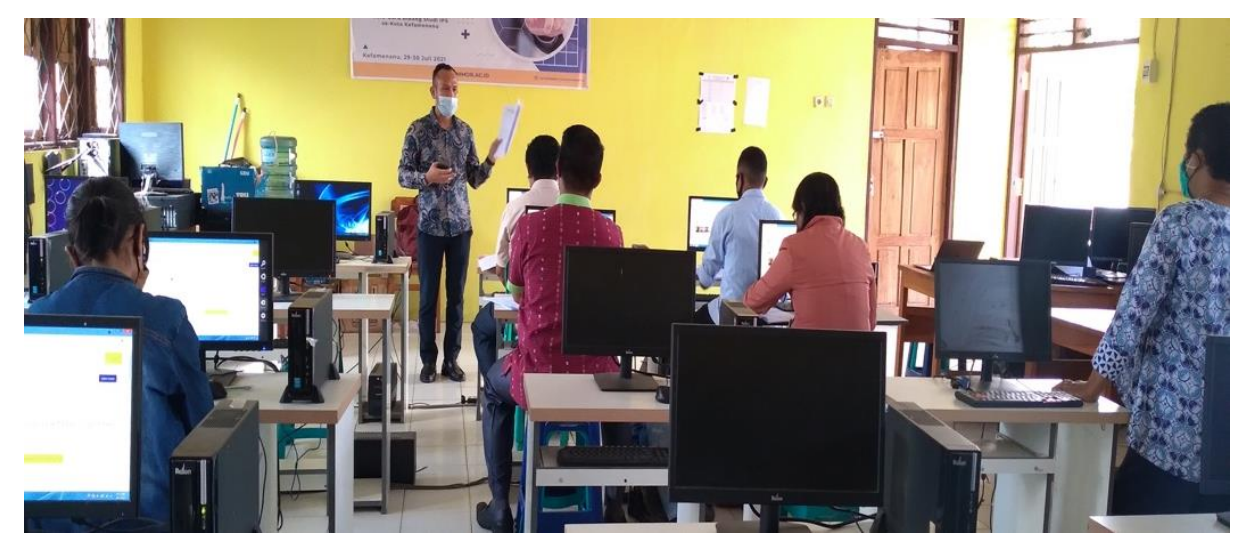

\section{Gambar 3. Penjelasan tentang Edmodo}

Kemudian peserta langsung melaksanakan praktek dimulai dengan melakukan create email, pendaftaran akun di edmodo sebagai Teacher, Students. Adapun menu yang dibuat adalah sebagai berikut :

\section{a. Note (Catatan)}

Pada menu ini users diberikan ruang untuk membuat sebuah catatan yang akan tercetak pada halaman "Beranda" edmodo, dimana catatan ini nantinya akan dapat terbaca oleh semua siswa. Note di sini sebenarnya tidak jauh berbeda dengan istilah "status" pada Facebook. Fitur ini dapat user gunakan untuk berkomunikasi dengan siswa, misalnya untuk memberikan informasi mengenai kelas di edmodo, menginformasikan materi yang harus dipelajari siswa, dan sebagainya

b. Alert (Pengumuman)

Alert (Pengumuman) merupakan jenis catatan yang lebih sederhana dari catatan yang terdapat pada menu Note, karena pada alert user tidak dapat melampirkan file dan 
hanya bisa ditujukan pada kelas-kelas tertentu yang user inginkan. Alert ini biasanya berisi pengumuman yang dianggap penting dan harus segeri siswa ketahui

c. Assignment (Penugasan)

Fitur ini memungkinkan guru untuk memberikan penugasan pada siswa dengan batasan waktu tertentu untuk pengumpulan tugas, selain itu guru juga bisa memberikan nilai langsung pada tugas tersebut.

d. Quiz (Kuis)

Fitur ini memberikan guru kemudahan untuk membuat berbagai macam jenis kuis yang dapat dikerjakan oleh siswa. Ragam jenis kuis ini yaitu a) Multiple choice (pilihan ganda) b) True false (Benar Salah) c) Short answer (Jawaban Singkat) d) Fill the blank (Isian pada bagian yang kosong) e) Matching (Pasangan jawaban yang benar)

e. Polling (Pemungutan Suara)

Polling ini merupakan fitur untuk mencari kesepakatan bersama berdasarkan suara terbanyak yang diberikan oleh siswa dalam satu kelas akan suatu masalah yang diajukan dengan lebih dari satu pilihan jawaban yang diusulkan.

f. Groups (Grup)

Guru dapat membuat lebih dari satu kelompok kelas dalam satu akun edmodo. Hingga. guru tidak perlu membuat banyak akun satu matapelajaran untuk banyak kelas yang setingkat dengan memanfaatkan fasilitas grup ini.

\section{g. Communities (Komunitas)}

Fitur ini memberikan fasilitas untuk guru agar bisa berbagi dengan guru lain yang ada diseluruh dunia yang telah memakai Edmodo. Guru bisa bergabung dengan beragam komunitas yang telah dikelompokkan dalam berbagai macam topik ataupun jenis bidang keahliannya, sehingga dapat berbagi pendapat dan masalah yang sedang dihadapi pada guru lain.

h. Progress (Progres)

Guru dapat memantau sejauh mana tingkat keberhasilan proses pembelajaran di kelas dengan melihat progres nilai atau hasil belajar siswa.

i. Discover (Penjelajah)

Dengan fitur ini, guru bisa menambah referensi tentang berbagai macam bahan ajar yang dapat digunakan. Guru bisa memasukkan kata kunci sebagai apa yang akan dicari dalam fitur ini, dan nanti akan ditawarkan pilihan berbagai macam media atau sumber bahan ajar yang bisa digunakan, baik secara gratis maupun berbayar.

j. Library (Perpustakaan) 


\section{Pembahasan}

Pada fitur ini, guru dapat mengkoordinir bahan ajar yang telah dimiliki, baik itu berupa materi, soal latihan ataupun link pembejaran yang sudah maupun belum digunakan.

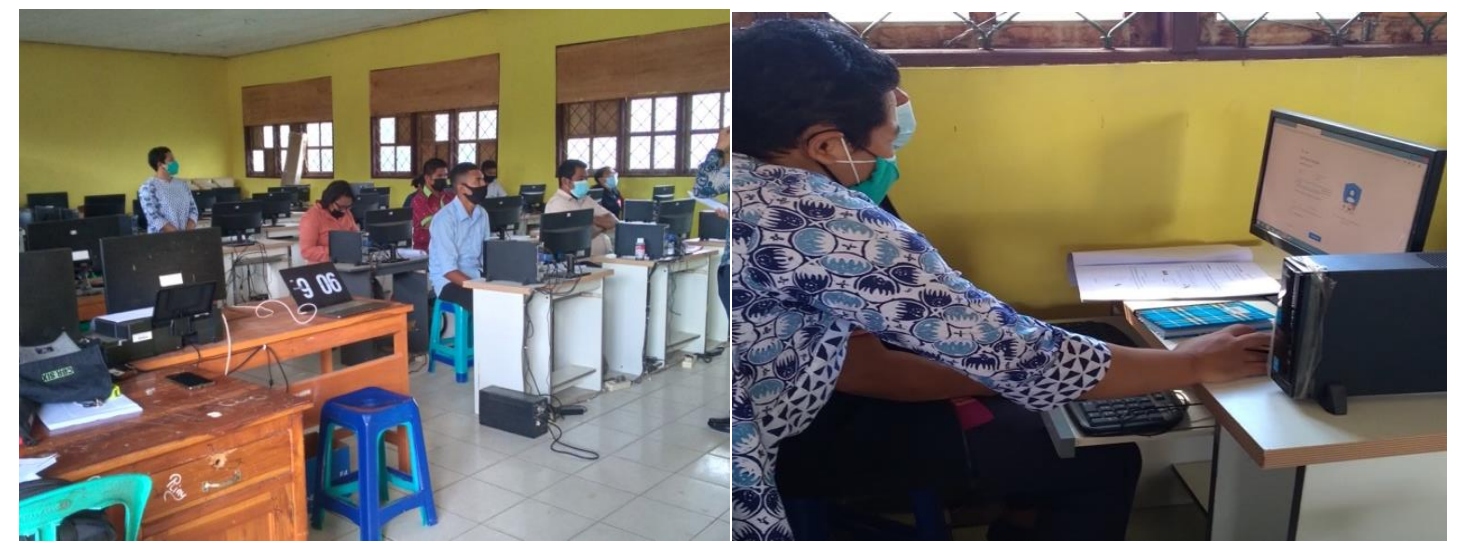

\section{Gambar 3. Aktivitas Pendampingan Pelatihan E-Learning dengan Edmodo}

Berdasarkan survei kepuasan Mitra bahwa para peserta pegabdian yang mengikuti pelatihan merasa senang dan puas dengan kegiatan pengabdian ini merasa sangat puas dan sangat penting seperti pada gambar berikut hasil tabulasi pengolahan data :

\section{SURVEI KEPUASAN MITRA}

PELATIHAN E-LEARNING DASAR BAGI GURU - GURU BIDANG STUDI IPS TINGKAT SMP SE-KOTA KEFAMENANU

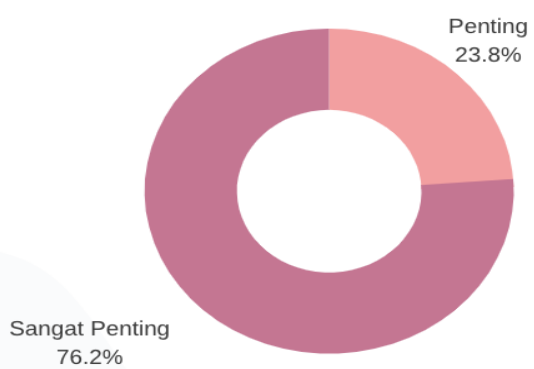

Harapan/Kepentingan

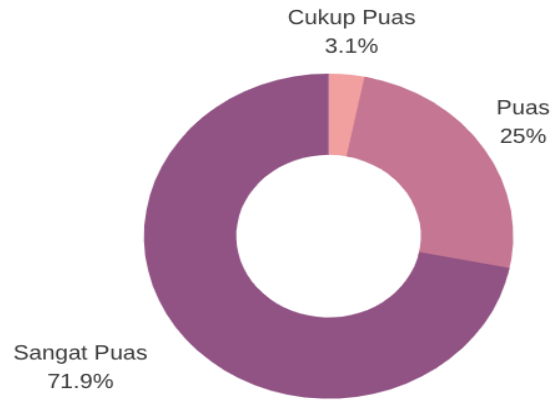

Kinerja / Kepuasan

Gambar 4. Survei Kepuasan Mitra

\section{KESIMPULAN}

Berdasarkan uraian pelaksanaan kegiatan pengabdian ini, kesimpulan dari kegiatan ini sangat menarik dengan jumlah peserta yang hadir berdasarkan jumlah undangan dan data 
yang ada di Dinas Pendidikan dan Olahraga Kabupaten TTU yaitu Jumlah Guru Bidang Studi IPS se Kota kefamenanu ada 18 orang. yang hadir sebanyak 12 Orang. Berdasarkan survey kepuasan dan tingkat kepentingan bahwa kegiatan ini dainggap sangat penting dan para perserta Pengabdian mersa sangat puas dan meminta agar pengabdian serupa dilaksanakan secara berkelanjutan mengingat pelatihan e-learning ini sangat membantu guru dalam membuat proses belajar mengajar di dalam kelas menjadi lebih bervariatif dan inovatif. Berdasarkan uraian pelaksanaan kegiatan pengabdian ini, dapat disimpulkan bahwa partisipasi peserta pengabdian sebesar $90 \%$. Peserta aktif bertanya dan mendengarkan berbagai hal tentang materi yang telah diberikan sampai kegiatan pelatihan e-learning berakhir. Peserta mengharapkan agar program serupa diadakan kembali dengan program pelatihan e-learning tingkat lanjut dan keterampilan pembuatan media pembelajaran lainnya. Para peserta merasa memperoleh wawasan baru tentang penggunaan e-learning dalam proses belajar mengajar, terlebih lagi e-learning dapat menjadi alternatif pengganti proses pembelajaran yang tidak dapat di selenggarakan di kelas akibat pandemi Covid-19.

\section{DAFTAR PUSTAKA}

Arizona, K., Abidin, Z., \& Rumansyah, R. (2020). Pembelajaran online berbasis proyek salah satu solusi kegiatan belajar mengajar di tengah pandemi covid-19. Jurnal IImiah Profesi Pendidikan, 5(1), 64-70.

Fadhillah, Y., Siregar, M. N. H., \& Aswan, N. (2021). Pelatihan Aplikasi Edmodo Untuk Meningkatkan Motivasi Belajar Daring Pada Masa Pandemi Covid-19 Di Exact Media Center Kota Padangsidimpuan. Jurnal Pengabdian kepada Masyarakat Radisi, 1(2), 5763.

Fuad, A. J. (2021). Domain Pemanfatan Teknologi Pembelajaran Di Masa Pandemik Covid19 Pada Pendidikan Agama Islam. Prosiding Muktamar Pemikiran Dosen PMII, 1(1), 763-776.

Habibah, R., Salsabila, U. H., Lestari, W. M., Andaresta, O., \& Yulianingsih, D. (2020). Pemanfaatan teknologi media pembelajaran di masa pandemi covid-19. Trapsila: Jurnal Pendidikan Dasar, 2(02), 1-13.

Holland, C., \& Muilenburg, L. (2011, March). Supporting student collaboration: Edmodo in the classroom. In Society for Information Technology \& Teacher Education International Conference (pp. 3232-3236). Association for the Advancement of Computing in Education (AACE).

Istikhoirini, E. (2021, January). STUDI LITERATUR: EDMODO SEBAGAI MEDIA PEMBELAJARAN MATEMATIKA DARING DALAM ERA MERDEKA BELAJAR DI MASA PANDEMI. In ProSANDIKA UNIKAL (Prosiding Seminar Nasional Pendidikan Matematika Universitas Pekalongan) (Vol. 2, pp. 11-18).

Kurniawan, H., Susanti, E., \& Arriyani, N. (2021). Menjadi Guru Yang Siap di masa Pandemi Covid-19, Melalui Workshop Penggunaan Edmodo dan google classroom pada pembelajaran Daring. Publikasi Pendidikan, 11(1), 63-67.

Kusmeida, M., Rodiyana, R., \& Febriyanto, B. (2021, October). EDMODO SEBAGAI MEDIA E-LEARNING DALAM PEMBELAJARAN DARING DI MASA PANDEMI. In Prosiding Seminar Nasional Pendidikan (Vol. 3, pp. 520-525). 
Lestari, P. A. S., Gunawan, G., \& Yulianci, S. (2020). Effectiveness of Online Lectures Using Digital Platform During the Pandemi Covid-19. Indonesian Journal of Applied Science and Technology, 1(3), 107-115.

Listiqowati, I., Khairurraziq, K., Abd Muis, A., \& Lisnaini, L. (2021). PENGARUH EDMODO TERHADAP PENINGKATAN HASIL BELAJAR GEOGRAFI DI MASA PANDEMI COVID 19. GEOGRAPHY: Jurnal Kajian, Penelitian dan Pengembangan Pendidikan, 9(2), 115126.

Purnawarman, P., Susilawati, S., \& Sundayana, W. (2016). The use of Edmodo in teaching writing in a blended learning setting. Indonesian Journal of Applied Linguistics, 5(2), 242 252. 